\title{
Knowledge of Sufism and the Symbolic Interpretation of Paradise Garden Design Concept
}

\author{
Muhammad Ahsan Bilal \\ Research Scholar \& Lecturer \\ College of Art \& Design \\ Universityof PunjabLahore \\ Sonia Nasir Khan \\ Lecturer \\ Department of Art \& Design \\ The Women University Multan
}

\begin{abstract}
:
As human beings we stand on the edge of two truths: the existing material world and the Spiritual being world. The knowing heart is the holy place, where these two dimensions meets and combined. In Sufi lessons the mortal heart of human is not an imaginary symbol but an objective organ of perception and intuition that reflect transcendent qualities in the world, for the assistance and help of other people. The Sufis, mystics of Islam, have been mentors of the heart for almost fourteen centuries. Their education and techniques purpose is to stimulate us and help us to wake up and clean the selffor Divine love. Sufism is the spiritual dimension of Islam. According to Sufism, there are two aspects of Islam: the outer part, which consists of the Shari'ah (the rules of Islamic law), and the inner part, so-called tariqah (the spiritual way). Together, these aspects lead one to haqiqah (the Truth). Sufism is another term for tariqah. This paper is an attempt to understand Sufism knowledge (true knowledge) and how this knowledge is related in world and with ChaharBagh (Garden of Paradise) concept, "symbolic interpretation of paradise garden" which is used by the Muslims in architecture. Sufism explains us that it is possible to understand the world beyond our thoughts. Those who dedicate themselves in Sufim exercise and practices eventually discover the state they can see things as real and true as they are or when you worship God as though you can see him.
\end{abstract}


Keywords: Sufism, knowledge, paradise, garden, concept

\section{Introduction}

The Acquaintances of the Prophet were devoted men who did performances of meditation and continuous Divine remembrance through its Names and also through Quran text repetition and after the death of Prophet they spread and educate the believers and at the beginning of eight century they became known as Sufis. Sufism is the name for Islamic mysticism means only understanding of heart and gnosis may give awareness in to some of its features of searching the One (Divine). It's a spiritual practice that neither depends upon rational nor sensual approach es but only the internal light and this light became stronger and clear as Sufi liberates himself from the worldly attachments. It graces the reflect of the Sufi heart and the Divine love makes the searcher able of bearing pain and even of enjoying all the efforts, struggle and conditions that God showers in his path in order to test him and cleanse his soul. Sufism is closely related to mysticism in certain forms developed by Ibn 'Arabi School, which helps to lighten the formative period of Sufi thoughts (Rosenthal 1988). The signs study and symbol of mystics helps in understanding the contribution of Sufism in the expansion of Islamic languages, literatures and arts.

There were several theories about the origin of Sufism. First comprehensive book on Sufism was presented by a German author and Professor F.A.D. Tholuck and he defined Sufi doctrine that was generated out of Muhammad's own mysticism (Schimmel 1975). Some scholars have put emphasize on the Neo-platonic impacts on the growth of Sufism. Sufism has mostly considered a normally Iranian expansion inside the Islam. The Earlier ascetic movement has Islamic origins so the original form of Sufism is a native product of Islam itself (Arberry 1992).

Sufism (tasawwuf) is the theosophical aspect of Islamic mysticism. Some consider that the name Sufi is so called for the reason that he attires a woolen dress (jāma-I sūf), others think that he is so named as he is in the first rank (saff-I awwal), others believe that the Sufis claim to relate to the people of the Bench who grouped around the Prophet's mosque (ashāb-I Suffa). In others scholars views that 
this Sufi name is derived from safā (purity). The source from sūf, "wool" is now usually accepted- the rough woolen attire of the first group of Muslim ascetics was their unique mark.

Sufism fabricated upon the norm of the believer's intention, the different ways and means of spiritual education and the exercises experienced and trained in the Sufi orders and the psychological stages of the advancement.

Sufi's believes threefold meaning of tasawwuf and follows the sharīa which is the Muslim act (doctrine). The tarīqa which is the mystic pathway (methods) and the haqiqa which is the Truth (Or ma'rifa "gnosis" In Turkey). Sharīa, tarīqa, and haqīqa are mutually interdependent. Sufis relates the tree roots with Shari'a, and the trunk and fruits with as the tariqa and the Haqiqa respectively. Sufis try to liberate themselves from worldly feelings, cleanse their souls, clear out their ego and reach to the Haqiqa that they carry inside. All Sufis try to reach a higher level of insight awareness in which they become united with their God.

The rule and method of Sufism are built on two theories. These are two testimonies originating from Quran and by which one declares oneself to be a Muslim:

1: 'There is no other god then God'. It's the concept of the Unity of Being

2: 'Muhammad is the Prophet of God'. It's the concept of Universal Prototype (or Universal Man).

The doctrine of the Unity of Being is the basis of Sufi metaphysics. ( Bakhtiar 1976)

Sufism is not a philosophy; in that it is built on the nature of Reality which is transcendent. It is only the spiritual Heart, the instrument of intuition which is above forms and capable of holding the Throne of God. The aim of Sufism is to collect all diversity into union, with totality of one's being in direct contemplation of spiritual realities. The journey begins with withdrawal from material world in which one is drowned. At this moment the diversity of soul (the psychic and sensory powers) 
disappears and idea of Unity fills the empty soul. The method of Sufism is derived from the second testimony of Islam and the Prophet serves as the spiritual model.

There are two types of Sufi; One is those who exercise total separation and aloneness and their only interest is their own salvation in the first "journey of one to the One". The Second One are those who after mystical experience came back in a higher, sacred state of mind and are able to lead and preach others on the true path.

Islam gives emphasis to knowledge and Sufism begins with the way of knowledge but transfers it to its main form, which is knowledge that lightens. The way of illumination comprises of three achievements:

1: Knowledge of Certainty (ilm-al yaqin). It gained from knowing the doctrine of spiritual path. This forms body of Sufism

2: The Eye of Certainty (ayn-al yaqin). Its knowing by seeing or observing for oneself. It consists in the spiritual methods and practices contained within the body of Sufism which leads to the Truth of Certainty

3: The Truth of Certainty (haqq-al yakin). It's the knowledge which illuminates. Knowledge gained through direct experience, gnosis

Dhikr and contemplation leads the disciple to the goal, "fanā" and baqā". Schimmel (1976) believes that Sufi should emphasis on perfect collectedness in contemplation (murāqaba), and from th is point he can achieve vision (mushāhada). It is a vision that can be defined nearly as proximity or presence that combined with "ilm alyaqin, "knowledge of certitude". The sincere "ilm al- yaqīn is the station that leads to 'ayn al- yaqin, essence of certainty or "vision of certitude" - the station of Gnostics - until it is completed in haqq al-yaqin, the "real certitude," which is the place of God's friends. (These terms are taken from Sūra 102 and Sūra 56:95). 
The gaining of doctrine is a centrifugal learning process, outward from the individual human form; the gaining of method is a centripetal learning process which must be actually experienced in order that the knowledge gained through doctrine may illuminate. Through spiritual practices one gains concentrative contemplation and thereby discovers the inner microcosmic Secret. (Chittick 1989)

The cosmos, known to mystics as a veil, (also referred in Quranic verses, known through traditions that God formed seventy thousands curtains of darkness and light and the cosmos has two aspects:

1: The universe is not God (as it is changing and separates us from God).

2: The universe is none other than God (as it discloses the Divinity).

So, cosmos not only hides but also disclose veils and make visible. For Sufi, world is translucent, because he perceives the supreme meaning of corporal and worldly things, and this is expressed and reflected in art.

According to Shirhindi the world is formed by God's everlasting and shapeless spirit ('ayn al-dhat). Shapeless spirit than gave rise to four stages of expression via a temporary realm known as (sha'n al-jami) or quality of wholeness. It serves as link between the created and uncreated realms and thus protecting the unique nature of God. The created realms contain a descending level order from subtle qualities (latifa) to gross material existence (kathif). (Figure1)

The first level of manifestation is Essence (dhat) or Oneness (ahadiyya). Unity (wahdat), is the second level that have two stages: "unity of essence" symbolizes the singleness of divine self and its traits are undistinguishable at this stage of recounting. In Sirhindi views here this point mystic recognizes constant, unitive consciousness (baqa'). Its lesser level is "unity of being," that comprises of the ideologies or seeds (usul) of the divine qualities (sifat). In third level of manifestation, Uniqueness (wahidiyya), the qualities are articulated; eight godlike traits (sifat-i dhat-i haqiqi) 
qualify transcendent being through affirmation, (i.e. knowledge, life and power). Eight traits of negation (sifat-i salbi) reject limitation in God whereas at similar time confirming His unique nature; the positive traits (sifat-i fi'liyya) define Him in relations related to the eight qualities such as life giver, creator, merciful and so on.

The manifestation fourth level denotes the created world and man together and named it the Circle of Contingent Existence" (da'ira-i imkan). On higher level of manifestation lies "world of divine command" ("alam al-amr) and it symbolizes the cosmos. Its direction is one of ascent and God's unity of essence is the goal or end of the journey. On the circle lesser level is the "world of creation" ('alam al-khalq), the unrefined corporal world containing the four elements and man's nafs or lower nature. The 'alam alkhalq signifies the microcosm, and its movement is one of descent. The world of divine knowledge denotes the mystical realm; the world of creation symbolizes physical existence, as well as mental life.

These two worlds are linked by an intermediate realm so-called "the world of ideas" ('alam al-mithal). Here intangible forms come first and their appearance in the gross physical world. These intangible thoughts are like the Platonic archetypes. They symbolize a creative, imaginal - not unreal - realm that provide form to the physical world. As a deeper realm of consciousness, 'alam al-mithal is also the realm of Sufi dreams, visions, and spiritual contact with trainers, that play a vital roles in unworldly life, giving guidance, mystical commissions and initiations, and directing disciples to their chosen shaikh.

The 'alam al-mithal is a transitional world where the world of divine command and creation, of ascent and descent, macrocosm and microcosm, coexist. Humankind is controlled at the stage of these two worlds as it contains all three dimensions of existence: body, mind and spirit. The link can be represented as such:

\section{Man}

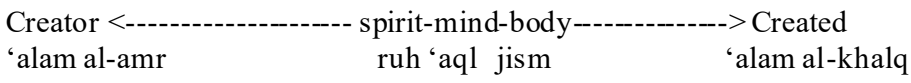


Each theory has its own methods of awareness and interface among the two worlds. The body, deep-rooted in time and subject to development of evolution and deterioration, uses the five senses to mediate the physical world. Because it's the role of mind to understand and link meaning to what the physical senses send, it too lies in the temporal realm.

The minds own five senses are similar to body such as thinking, imagine, memory, desire and hallucination.

So far as mind and body are subject to temporality so separately, they cannot identify the transcendent realms. Still, they use symbols to denote the transcendent. Just like mind and body, the soul has its specific inward senses (hawas batini). These inward senses have a physical similarity in a link of minute centers in the human torso so-called lata'if (sing. latifa). The lata'if has been defined as minute centers, fields, covering. The lata'if have no permanent position and it could be somewhere in the body and linked with only organ of body which is heart and is set in the "World of Divine Command". It means soul and physical body and is in the "World of Creation", representing spirit's complete birth into the visible world

Each tariqa or mystical pathway has its specific distinctive method or rule principle for ascent to the transcendent thru the lata' if.

Sufism believed that "For the Knowledge of Self ', each form remembered, recalled and expressed again, so that it may come to recognize Self and as Divine is Infinite, so Knowledge of Self is also a part of Infiniteness. Knowledge of Self itself is a triplicity of knower, knowledge and known and together with Will (by hearing) and Command (by obeying) one reach to the Absolute.

Extract from Quran, Sufi perceive six mystical centers (Lataif-asSitta or "the six intricacies") such as Qalb, Nafs, Ruh, Sirr, Akhfa and Khafi. These are psych mystical "organs" or, at times, facilities of sensory and supersensory perception. They are fragments of the self just like glands and organs are fragment of the body.

Sufism is just like awakening or cleaning the mystical centers of perception that asleep in each person. After going thru this method, 
the mystical seeker (dervish) reaches a definite type of achievement or become a complete Man.

In Sufism the language of expression is that of the Archetypes or Divine names and Qualities and through these archetypes as Names of God that one invokes, calls upon the Absolute, whether one is transforming one's own soul or soul of a particular object. As Divine emanation is a dual method: intelligible and sensible so this emanation brings this Archetype into clear reality and at the same time they occupy a middle position between the Absolute and sensible world. So they are actualized in the sensible, phenomenal world according to the preparedness of the particular sensible form which they take on.

Archetypes are classified as Names of Essence of Action, Qualities, Majesty (Jalāl), Beauty (Jamāl). The mystic invokes God through the Names of Beauty. The Archetypes are minimal, forms that are outward and basically comprehensible, but inward and probably sensible. External forms perform as realistic containers for the Archetypes that are sequentially understandable vessels for the features of the Absolute through the world of symbols. In Sufi terminology the universe is the shadow of the Absolute.

Divine Breath is nature itself and nature holds all form of expression in a possible state of readiness in which they wait for the presence of the Breath of the Compassionate, which is the Spirit, permissible to be recognized (Bakhtiar 1976). One wishes to known the Breath of the Compassionate in order to recognize self because the self is the form of Lord in shape. One's deepest presence is straightly uttered through speech, so prayer (zikr) is the source of attaining the very substance of things in us.

In Sufi view, universe is being rebuilt in each moment. There is continuous, instantaneous expansion and contraction. The world is in profound motion, rising to the vertical axis inside entirely things to encounter the origin of the Absolute in present forms. The movement arises in arranged, consecutive style, according to certain pattern and we are ignorant of this. Ibn 'Arabī stated: 
"The wonder of the wonders is that human form and all other created things are in a perpetual process of ascending and yet one is not ordinarily aware of this because of the extreme thinness and fineness of the veil or because of the extreme similarity between the successive forms. How splendid is God's description of the universe, and of its perpetual renewal with each Divine Breath which constitutes an ever new creation in one single entity!"

\section{(Schimmel 18)}

This constant change of forms is constant changing of ourselves and it leads to knowledge of Divine. As soul approaches the transformation from sensible to spiritual and heart is the instrument of institution. So, it's the heart which finally unites with Spirit. As soul is attached with body it descends from world of Light to world of Darkness and mystic's soul discover where it is, where it came from and from where ability it is to go. Soul is united with spirit or intellect which sought knowledge. As Prophet said: "One who knows self, knows Lord"

As soul comes from nonphysical world so its first form is vegetative soul (nafs-i- nabātiyyah), allowing the form within womb to have same function of feeding and growth like plant. As the form grows in the womb, it develops the animal soul (nafs- ihayawāniyyah), in which it acquires the ability of motion. At birth the animal form is completed, as form exhibited various desires. However, not until adolescence does the soul pass from potential consciousness to being able to actualize consciousness with the appearance of the rational soul (nafs- i- nātiqah). The quest begin s and the ability to transforms self-come into existence and first journey started to change the nature to become a form without desires and second stage is saturation.

Soul consists of threefold hierarchical structure within the human form:

1: Sensory this is the denial of sensory pleasures in the journey

2: Psychic which consists of five internal senses: common sen se, imagination, intelligence, memory and active imagination or 
intellect. The function of them is defined along with meaning and form. These inner senses (psychic) are part of soul, in cluding the outer senses, which changes the mystical Quest to spiritual becoming and combine with the Spirit.

3: Spiritual and the Soul consist of three spiritual stages. The first stage is the awakening to the consciousness of the existence of passionate, egoistic soul, soul which commands (nafs-i-ammārah). At the second stage called accusing, reproaching the soul (nafs-1lawwāmah), the soul aware of its own imperfection and blaming self. The final is the spiritual stage of peace (nafs-i-muta'innah), when it reintegrated with the Spirit. As soul is of Divine origin within human form; for God breathed his spirit into it.

The human form is the place of gathering. It gathers two separate dualities:

1: inner duality that exists within the form and essentially the vision one has of oneself. The inner duality of men and women are same

2: outer duality that exists between forms; it is the vision one has of oneself as reflected in another form. The outer duality consists of physical forms of man and women

It is only through forms that the gathering of opposites may be accomplished. The creation of concrete forms, in which one can come to contemplate the Divine, is the very reason for the existence of art.

The process soul come into the arc of ascent and accepts the mystical Quest that lies in the Sufism methods and technique that are based on the ability of concentration. Concentration is very difficult act. Thus, all methods of Sufism seek the center and without ability to mediate or contemplate it is impossible to control the urges of the soul. The method is one of spiritual alchemy. Through transformation, the substance of the soul is changed. Sufi believed that the "Knowledge without practice is like a tree without fruit". Practice (Method) is never same for all people whereas the doctrine is. 
The first step is to seek Shaykh (spiritual master) (mostly Sufis have been guided by prophet Khizr) whose purpose is to clean the disciple heart so the disciple reflects the splendor of Divine Unity. The arousal arises with growth, for that is the centrifugal motion away from the contracted ego. The awakening may occur in one of two ways:

1: One either has an extraordinary experience which enables one to overcome one's habits

2: One seeks spiritual retreat (khalwat) by isolated oneself in a cell and spiritual retreat devoted to the remembrance of God and forgetting of self. It is an aid in achieving a state of permanent inward retreat, on the traditions of the Prophet, who used to retreat to caves in mountains. In khalwat, forty days the Sufi repeat ceaselessly day and night Divine name and fast strictly and gained illumination. Some mystics obtain after few minutes, some after several days or weeks. The spiritual retreat can remain effective after one leaves khalwat, only if one continues to remember.

To some, this remembrance is expressed in arts and crafts. Spiritual practices need the support of external forms, ritual artifacts such as Quran, the place of prayer (mosque), the niche and calligraphy.

Spiritual Method is Sufism is the mystical path. It is like a flight of steps that took the follower (sālik) to heaven and with this he patiently and slowly reached the high level of experience.

The route to the Hidden starts at the center, revealed in man thru the internal intellect that is covered through the ego. By rendering this veil mystic will be able to discover Self, recognized only through introspective meditation, prayer and perception.

Follower has to concentrate and work to work night and day, to clean and cultivate the field of the soul. (Schimmel 143)

i): Initiation symbolizes the death and rebirth of the individual ego. It connects the seeker spiritually to the infinite. It's a mean of opening the door and going on depends upon one's will. The 
various orders Sufi Saints received great power along the spiritual way which comes from God.

The expert should try with his entire self to God_ikhlās, "complete honesty, "and quit self-centered feelings in the service of God and this is the main duty of every mystic.

2: Meditation (fikr) function is to concentrate heart on God and look inward.

3: Invocation is also very important part. In Sufism, meditation (fikr) is the submissive matching part of active prayer (zikr) and without praying a name of God, there is no meditation possible. This brings the Divine Existence into the sound as human speech is in special relationship to soul. With Zikr,

a) We remember God

b) We pray his name

c) We remember Him

Within invocation there is a pattern of meditation which varies according to the master and the order. By invoking God we give our existence back to Him. There is a Divine Substance in the air, and God takes our breath and light and integrates it into His being.

4: Wird is another important part of Sufism. The Sufi begins by performing "wird' or litany which is a bridge between the daily prayers and the invocation. Every order chooses a verse of Quran or a prayer of Prophet which is repeated a certain number of times. In the wird there are three stages: purification (death), expansion (love) and union with God. The repetition continues either alone or in assembly aloud or silently, until Sufi identifies the heartbeat with Divine Presence.

5: Contemplation (shuhūd) in which one concentrates on a visual image or on an idea which must have a Divine Quality. One either isolates this in mind or puts it in a formula and is often performed with bodily motion so that soul may dissociate itself from the body. 
There are virtues for the attainment of Divine love. The Sufi internalizes three basic spiritual virtues that were stemming from Quran. These three virtues internalized when we see the universe as symbolic of Divine Presence.

1: Humility (khushū) is the realization that God is every thing and we are nothing. It's the awareness of two things: firstly only God exist and we are non-existent and secondly every human being has something to teach us.

2: Charity, is the realization that we have nothing, and everything comes from and belongs to God. It's a virtue connected to nobility and at highest level is giving self to God and to invoke the Name of God.

3: Truthfulness is to see things in their transparent state or to see things as they really are. It lifts us to the plane of existence to the plane of knowledge.

The Five Piers and Sufi Way of life are necessities for selfdiscipline.

When seeker is at entrance, it's the start of journey to the Absolute. There are several conditions. The gateway leads to door which must be entered. In Ling views, these are second stage of journey. The time when seeker enters the doorway, than he need actions, encounter (conduct) and its third stage.

After encountering one learns good habits and more perfect self and its fourth stage. After goodness of character is created, for best purity of forms follows the principle which becomes the foundation of one's life; its fifth stage. Difficulties happen in the phase of valleys and later this one arrives at the degree of different incidental otherworldly states and its seventh stage.

In the eighth stage the spiritual powers make their appearance, known as sanctity. In the ninth stage of journey one becomes careless in oneself and is absorbed in Divine and the Divine Self" and this stage is known as realities. The tenth stage is the phase of existence in God, the highest goal, the point of union. 
In coming back from Divine Essence to the realm of nature-man, there are seven stages, from sunlit to shadow. Again after coming back, one crosses these seven phases in reverse order, ascending through seven indirect, non-physical facets of self.

The Sufi 'path' contains seven 'stages' - repentance, self-denial, repudiation, scarceness, persistence, belief in God, and contentment. Likewise, there are ten mental 'conditions' relating with this discipline such as ; meditation, closeness with God, fear and love, expectation, wish, closeness, serenity, observation, and certainty. The earlier involves one's personal effort while the later are mystical experiences that man has no control.

The word state means a trait that is not eternal. According to Sufis, whatsoever alteration come in the heart by clean love from the path of the Truth, without the intention of seeker, is so-called spiritual state. (hāl). It come in the spiritual heart via desire, thirsting, anxiety, and intuition. It can arise as a spark or remain extended but not eternal.

Spiritual states are instantaneous successions and alterations reflecting a transient spiritual mood. Their arrival and disappearance depend solely upon God. A spiritual state refers to a multiplicity of emotions in the soul. These emotions reflect both discontinuity in their order and difficulty in their stabilization. The transient spiritual state, the internal reality of self which is unstable to begin with, becomes stabilized as it moves towards tamkin: strengthening, stability, symmetry. Weak soul cannot persist in the act of spiritual state.

Spiritual stations are distinct from states and come to certain act and certain complications. They are everlasting achievements. However the three chief are: Repentance (tauba), Trust in God (tawakkul), Poverty (means absence of desire for wealth) (Baldik 1989).

These lead the way to serenity, to distinct marks of love (or to gnosis), according to mind tendency of the wanderer. 
The station has places of staying and a respect for center, and corresponds in visual terms to geometric forms. Mystical stations among which the searcher regularly moves are:

i) Contraction/expansion (qabd/ bast),

ii) Gathering/separation (jam '/ tafriqah)

iii) Sobriety/ intoxication ( sahw/sukr)

iv) Annihilation/subsistence (fanā'/ baqā')

v) Presence/absence (shuhūd/ghabat)

Every station has its own science like geometric forms have beginning and an end which relates to the law of similitude and symmetry. As geometry brings order and structure to the seeming chaos of nature, spiritual stations act as organizing forms for the soul.

Mystic attains the station of gathering (jam) has resisted the physical world of phenomena, while the mystic who attains the station of separation (tafriqah) is ensure commitment and God, although close to the magnificient world and differentiating the Absolute from its creation. Whereas the station of gathering is to 'behold one moon plainly,' to be conscious of nothing but Unity, the highest station of gathering is the 'gathering of gathering' (jam ' al-jam ') that is to recognize Divine Unity in three features at one and the similar time: Essence, Creator, Creature; or Essence, Qualities, Actions; or Law, Way, Truth. Stations are fulfilled only through their opposites.

In the station of fanā', there is complete lack of consciousness of object or ego; one is moving towards darkness. There is not even any consciousness of the experience itself. There are no images.

In the station of baqā', the mind reawakens to the remarkable world, but now these shapes forms and metaphors are objective shapes forms in which the Divine Essence reveals itself. In darkness one is moving towards light and this light is the manifestation of the Divine Knowledge.

In Sufism, the heart is key spiritual organ. The Heart of the mystic is full moon; his soul is as the darkness of the night. The Heart is 
now full, totally reflects the sun which brings peace is annihilated in the Light of the Absolute, leaving only the Absolute Peace of Unity.

Symbolism is the beautiful and sacred indicators of Sufism in Islamic society. Symbols are the means of communicating Divine truths that transform us and take us to the high states of nature form, from which they emerge. Recognized as a world towards themselves (alam-i-mithal), they are the dwelling of meeting among the Archetypes world (intelligible) and the phenomenal sensible world.

In Sufism, metaphors emerge from Quran and hadith (tradition). By seeing, through symbols one can recall to pray continuously. Symbols are truths confined in the nature of things. The whole journey in God is through signs and symbols where one is continuously conscious of the high truth in things. They depict both Divine perfection and immanence and reflect together the universal characteristic of creation and the particular part of tradition.

For Sufi, the symbol is seen in the presence of the theophanic light, which is knowledge of light that arises after the mystic move through Divine Law. Gained the Knowledge of Certainty via knowledge of Sufism principles, perceived through the internal meaning of performs and rituals thru the Eye of Certainty and reached the center to gain the Truth of Certainty. This theophanic light is not seen but enables one to see the form through which it shines.

Artist's (who gives symbol its concrete form) image, may be an extension of a super-conscious attitude. This may be termed as spiritual awakening. One is inspired by universal forms but inspiration finds expression only in one's tradition. So the forms that appear in art and crafts; the ideas are reflected, expressed and recalled in the intellectual development of each tradition. However the sign has been reveal and the Sufi believes that 'man cannot produce signs: he is transmuted through them.' 
Geometrical interweaving no doubt symbolizes the utmost logically sustaining form and is true direct manifestation of the knowledge of the Divine unity hidden under the vast variety of the world. Divine Unity by itself is behind all depiction, as its nature, that is total, lets nothing remain separate from itself.

There are two types of Symbols

1: Universal/Natural Symbols that are signs as emerge in the nature of things and are trans-cultural.

In Sufism, universal metaphysical symbols expressed particularly in architecture, music and calligraphy and stem from Quran, the Word which contains Names and Qualities. In SCHIMMEL views, signs that are related to light, sound and intelligence have the most deep expression.

2: Particular Symbols differs according to various customs. They are functional or intelligible forms blessed by God by revelation it become means of Divine Grace and hold the theophanic light that converses an aspect of perfection on a certain tradition where they are exposed. Particular symbols divided into many categories according to the means of expression. In Sufism they are interpreted through " $\mathrm{ta}^{\uparrow} \mathrm{w} \overline{\mathrm{1}} \mathrm{l}$ ", the art of spiritual hermeneutics. These categories are:

(a) Cosmological symbols are natural symbols and have inner symbolic meaning.

(b) Psychological symbols that represent thought, feelings.

(c) Religious symbols are iconic symbol that denote a definite concept in a given religion. Sacred symbols in Sufism begin with the place of retreat (khānaqāh). Sufi shrines serve as important religious symbols for they relate to higher level of Reality.

(d) Particular interpretations of universal symbols 
With the help of symbols, one progress closer to the alteration, the aim of the Quest.

One of the utmost attractive sign \& symbol that appeared in Islamic carpets, architecture and poetry is Garden of Paradise."

Gardens are related with symbol of Paradise or al-janna (the garden). In Quran, the description of heaven is explained as flowing water and trees with fruits that suggest its importance to man. According to Quran, the good deeds have reward that is the place with shaded trees and gardens with fruits, flowers and flowing water. The Quran gives 8 different titles from Muslim scholars draws 8 different stages of Paradise.

a. Jannatu- al- khuld (al-furqan, 25:15), can be so-called as Garden of immorality or eternity"

b. Darul- as- salam (al-anam, 6:127) could be so-called as "the Abode of Peace".

c. Darul- al- Qarar (al Mu'min, 40:42), can be called as "the Garden" or "The Garden of Bliss".

d. Jannatu-al- adn (al-Bara'ah, 9:72-73), may be so called as “ the Garden of Eden ( Everlasting Bliss.)

e. Jannatu- al- Ma'wa al Sajdah, 32:19), could be entitled as the Garden of Hospitable homes or " the garden of Retreat"

f. Jannatu-al- nain ( al-Maidah, 5:70), may be so-called as “ Paradise" or Heaven"

g. Illiyin (al- tatifif, 83:18), may be termed as similar.

h. Jannatu- al Firdaus (al- kahf, 18: 107), may be so called as "the Garden of Paradise"

This shows that Paradise, in all forms is a garden and this garden is the last journey stop for all humans who live their worldly life according to the Holy book preaches.

Depiction of Paradise garden is in Muslim architecture. In Islamic history there is one garden plan, with a slight variations and known as "Chahar-bagh," or the four part garden lay out with axial causeways that interconnect in the center. Flowers were usually 
embedded parallel to main water channels and also connect to the minor Portions of Chahar Bagh design. (Kausar et al, 1990) Cypress and blossoming fruit trees were usually fixed along the garden main axis. The Muslim rulers tried to construct manmade replications of the Quranic images of Paradise on earth.

A Paradise Garden was created on the classic Char-bagh design, in which division of 4 parts water channel was created that were depicted as 4 rivers of paradise, as defined in Islam. (Ruggles 2009 ) (figure 4).Plantation of trees with fruits and other flowers and roses assemble in geometrically set beds below the level of closest pathways, gives a feeling of walking on a carpet of flowers.(figure 3)

The garden is conventionally an enclosed area that was planted with trees and enclosure planted with trees surrounding a central main pavilion (Critchlow 1976) The complete seems like a mandala, giving each together centrifugal o motion, outer in the paradise of nature, also a centripetal motion inmost along its four entrances, to the water, its mystical centrum. Creating continuous wavelets, the fountain restore the circle of conscious growth and reduction. (Figure 2) The idea of the garden is an image of the universe. John Brookes (1998) stated the idea of garden of paradise as that on the left a centrifugal, or outward-directed, energy exclude through the building into a natural paradise; on the right a centripetal, or inward-directed, energy runs in to a fountain, that in order creates ever growing waves, so continuing the circle of growth and reduction.

Chaharbagh model of the Mandala with four corners... a mandala that symbolizes "wholeness", a living thing, and a harmonic stability. The center of Mandala is the basis of energy and from this energy thought is nurtured. The correspondent of this energy source is the fountain in the garden, as water is the vital source of the life of the garden, the energy source of the mind is vital for life and rebirth of human soul. For the garden to grow, this "water of life" must be channeled and circulated to every portion of the garden in a well-adjusted and harmonious way. (Figure 5)

Chahar Bagh design is basically square enclosure within more four gardens are present 
(Lehman 1980). According to Sufi thought, the square is the symbol of the material world and the physical experience; it's the symbol of the earth. It is also the shape of the plan of the temple of the Kaaba: the meeting point between heaven and earth.

The Sufi dwells in the paradise of being One with the Beloved in the here and now, not looking to the promised paradise of hereafter. For Sufi, one who does not find the Truth in this world will not reach it in the next. As it is written in Quran, "Whoever is sightless in this realm will be sightless in the next, and yet further astray."

Garden of Paradise in Mystics view is that "The garden is an earthly replica of Paradise..." (Baldick 1989)

Beautiful symbol appear in Islamic poetry, carpet designs and in Islamic architecture.Paradise is narrated in the Quran (55:45-75) as of four botanical gardens and are translating as four phases from which the mystic moves to inner journey. These four gardens are so-called

1) Garden of the Soul

2) Garden of the Heart (These two gardens Soul and Heart, Symbolizes the totality of perfection of human nature)

3) Garden of the Spirit

4) Garden of Essence

Each garden consists of three objects: a fountain, flowy water and fruit of trees.

According to Shah Ni 'matullāh, the four letters A LL H corresponds to the mystic's Heart, Intellect, Spirit and Soul.

The Perception of Heaven with some major elements is:

a) Tree: “A good word is a good tree. "Qur'an

Trees element is obviously in explanations of the Islamic concept of Paradise, in both aḥādith and in Qur'an. Each one of these trees 
symbolizes diverse ranking order, diverse features, represen tation of the World Tree, the cosmic and supracosmic Tree of Life, that extends along the span of the Axis Mundi passing through and joining all of the created order - all worlds and beings - at the center. Ibn ${ }^{\varsigma}$ Arabi describes the Cosmic tree in its macrocosmic aspect grows on the topmost of cosmic mountain and the entire cosmos is perceived as a tree Tree of Knowledge) that has grown up with the seed of the Divine Order .'

The Tree has spread down its roots and extended up its stem and branches so that this world (the world of Symbols and Archetypes) all confined by this Tree. It manifest in macrocosmic aspect so hidden in microcosmic form.

It is the sign of wisdom which through roots in meditation and carry fruit of the Spirit. The most significant thing in Sufism is that they identify the world its creature as an expression of Divine Beauty

b) Water and Fountain:

The Persians arranged and organize their gardens of paradise adorned after this heavenly prototype, separating off with four 'streams' that were nourished through a main fountain that itself defined both the tree and the waters of life. Diffuse out to the four key points, the garden canals split up into a square that is representative of the revealed universe.

The exuberance of a well-nourished fountain looks as if to resist gravity. It is full of life and spirit and inspire the heart of all tho se who look it. It rushes like cleaned and crystal like diamonds to be filled with the glow of light. The waters run deep in the soil of one's personal soul and can appear only after one has walked and underwent pain of an excessive thirst in the desert of tough existence. The fragile fall down soul will be come into contact with action thru the irregular mount of greater will and the clean fountain of everlasting Truth and Wisdom will overflow the heart. Thus, in other depiction of Paradise, the Quran hints the river of water and of wine devoid of identifying any variations of level. It can be said that wine, being "warm," has the "subjective" meaning of Gnosis in relative to the cold objectivity of water that symbolizes Truth, the Object of Gnosis. 
Moreover, to this objective-subjective allegory, the fountain has further purely subjective meaning of instant opening of an eye, which is hidden in the term "ayn that means both "fountain" plus "eye." This subjective symbolism is further significant, because the reason why men see only "the scum of illusion" is that their hearts are toughened, or in other words that "the eye of the Heart" is locked, and truly it is not the vision that is blind but the hearts, and in one extremely suggestive passage Quran impresses us to imagine the prospect of a fountain flowing from the Heart.

c) Flowers in Garden:

The source of love is the Divine Center. There are many other names for the Divine Center: Cosmic Soul, Cosmic Consciousness. Our soul has this amazing capacity to reflect the infinite love emanating from the Divine Center. Rose symbolizes the Divine Love indirectly because rose is the symbol of the heart which is the soul.

"The Rose Garden is a symbol of Paradise and is the dwelling of the mystic marriage, the union of opposites" red, radiant red - is the color of God's 'cloak of glory,' the Rida' Kibryat. This is one explanation why the rose is so dear to Muslim thinkers and poets and mystics.

Every other flower in the garden could be seen in some religious connection. The violet for instance, wearing a dark blue purple garment as it were, and as a very modest flower is often seen as an ascetic who sits modestly with his head lowered on the green prayer rug, namely the lawn.

Paradise four gardens are taken as four phases along which the mystic moves to the inner journey. ( SCHIMME 1975)

1: Garden of Soul: It is built by gateway of senses. In order to move in, mystic collect the inward senses or (intuition). The mystic encounters perlis (jinn or psychic forces of nature) in entering this garden. This perlis pulled the soul away from centre by physical 
desires. Here mystic through intuition preserve soul step beyond the gateway into the garden of Soul proper. The garden contains three things:

a) Fountain that symbolizes perception of particular forms and idea. Mystics gains Knowledge of Certainty.

b) Flowing water that symbolizes light'. The information that spouts from the Fountain of Spirit, drifts to the Garden of Heart and here nourishes the facilities of instinct that helps to remove desires in the Garden of Soul. The water also give growth to the trees.

c) Fruit of trees are the trees (thoughts) by meditation grow fruit. The mystic in a sense seals the gateways and in the Garden of Soul through meditation, is able to make habit of thinking function in its utmost form. Through meditation is able to understand particular object perception beyond their particular meaning to their Archetypes in the Garden of Heart.

2: Garden of Heart: It is structured by feminine principles of spiritual becoming. Intuition stayed in the spiritual Heart and also known as instrument of gnosis or illuminated knowledge.

To enter in it the mystic must leave the reason behind. As mystic enters this garden further perils appears and there is danger of falling due to the potency of psychic forces. The mystic enters the garden and find fountain, flowing water, fruits and tree. (Lings 1975)

a) Fountain is the Fountain of life or else Immorality. Through drinking from this fountain, the mystic achieves the Eye of Certainty so reaches to straight contact with the Spirit as the water of this fountain spring from the Garden of Spirit.

b) Flowing Water is in garden is "Intelligence", and understanding that has been lit up by revelation. As mystic abandoned cause that relates with practical world, instead of this his soul is fed by the Intellect of Spiritual world.

c) Tree and fruits in garden is the Immorality or Tree of Life. Its products are of collective meanings that relate all forms 
and imageries to the inward similarity that exist within all things and have imprint upon the soul.

Heart's Journey is beautifully described by Sufi interpreters of the Quran. The journey is through the way of physical attachments and awareness of the lower world until the Heart reaches the setting of the sun, the point of awakening. It sets in a muddy spring, the water of materiality. The Heart finds near this spring of darkness, the physical, sensory, psychic and spiritual faculties of the soul. The Heart subdues anger and lust by means of asceticism; at the same time, it strengthens its spiritual faculties of mediation and contemplation. Discernment within is awakened. Thereafter the Heart follows a second journey, the journey to God through spiritual purification and sanctification until it reaches the rising of the sun, the Spirit. It finds its spiritual faculties unveiled in the light. Then it follows the journey in God until it reaches a point between the two barriers: its Divine nature and its original fallen nature. Here temptations increase until it builds its own wall out of knowledge and action stemming from the Divine Law and spiritual practices. Only by building this wall is the Heart able to drive away the demonic psychic forces. Invocations and intentions than helped the adept further for the Divine love.

3: Garden of Spirit: After gathering the particular and universal meanings from these two gardens, the mystic move inward to the Garden of Spirit. To enter this Garden of Spirit, the mystics' potentiality has been reabsorbed in primordial nature and the mystic is on verge of union with the Secret, the spiritual center. Perlis still present themselves but the mystic reabsorbed in the light of Muhammad (ص), the Spirit. At this point the mystic sees with the eye of this light and sees all light unveiled.

This garden is structured by higher and lower part. The lower part contains the seven Prophets of one's being which corresponds in the macrocosm to the seven visible planets. At this division between the lower and upper parts of the Garden is the flowering of the Tree of Knowledge. Its origin lies in the lowermost section but fruit produces in the high sections. The higher part of this garden is known as the Garden of Refuge. 
The mystic move in to the Garden of the Spirit and discovers a fountain, with water that flows out for the fruits and trees. (Bakhtiar 1976)

a) Fountain is the Fountain of Knowledge that illumined through the Spirit. It is the meditative Truth of Certainty, the awareness of light, that is the knowledge of the Oneness of Divine Qualities. The Fountain of Knowledge seems like veil of light behind of which shines the Light of Essence itself.

b) Water in this garden the water that gushes similar to the oil in the Verse of Light that burns yet no fire affected it.

c) Tree and fruits are tree is the Tree of Knowledge that nurtures near the fountain and it stretches itself to the uppermost boundaries of the Spirit. The fruit of this garden is the "date' from which the Virgin Mary nourished herself after giving birth to Spirit. This fruit symbolizes the contemplation of Divine Light and appearance of Divine Majesty and Beauty.

4: Garden of Essence: Finally mystic enters in this garden. The mystic enters by losing all traces of individuality and in the polished mirror of Sufi with empty of human self, Divine Self is seen. The perlis here is the mystic individuality. Its form contains both feminine and manly norm, uniting in the stage of annihilation, recreated in the illumined knowledge of the Unity of Being. Upon entering the mystic finds:

- Fountain is the fountain of Knowledge of Unity of Being

- Water is the water which flows out is clean Light'

- Fruit of tree is pomegranate and is the fruit of this orchard which is the sign of amalgamation of multiplicity in unity in the station of Union, aware of Essence.

Expended in the sunlit and no individuality remains, the mystic has reached the goal of the Quest which is the Truth of Certainty.

Now mystic through the Arc of Descent came back to the phenomenal world in a state of subsistence. Seeing the gardens in reverse order, mystic complete the circle in knowing, 
i) Garden of Essence is as Light where Knowledge of Unity gushes forth.

ii) Garden of Spirit symbolizes by the sun where Knowledge of Oneness of all Divine Qualities gushes forth of itself.

iii) Garden of Heart is whose water flow from Intellect and whose Fountain of Life is fed by the Fountain of Spirit as moon receives the light of the sun.

iv) Garden of Soul is as moonlight reflecting the Unity of Being.

Subsisting through God the mystic is now Sufi and has returned from the Quest.

Rhythm and symmetry is created in Chahar-bagh Design because Islamic art forms are derived from seeing within nature using eye of wisdom. Islamic artist through order within order and symmetry harmony, and patterns with rhythm of cosmos lifts the mystic's spirits. This knowledge of inner wisdom is showing the will and law of God thereby tracing a path of "truth". Thus Islamic wisdom (tawhid) is "pattern within pattern."

Thus, it can be concluded that Sufi method seems like illogical and at times even unsafe. But when one goes into its deep philo sophy of performs and exercises fully, than one can see that such practices are beneficial for individual. The aim of Sufism is to guide man from the worldly forms to spiritual world. Form is the curtain of the world of spiritual, and simultaneously it is its sign and stairs thru which combined with it can be achieved. Form has become refined and polished via traditional art and knowledge, the obscurity and opacity of multiplicity has been lifted. So it looks just like a mirror, that reflects the splendor of the mystical world.

In terms of architectural design the creative act follows the same paradigm as the Islamic thought. In the overall and perpetual process of transformation of nature, the formatting shows the unity of the Spirit of God in the diversity and plurality of perishable and evanescent bodies. In the "chahrbagh paradise garden concept, all the physical components are doted of symbolism, turning around a single and unifying Centre. The Sufi breath in this life that one 
might consider as the visible enclosure of paradise. Islam itself is extremely linked to the part of the Divinity as beauty and this part is mainly emphasized in Sufism.

The Sufis are the producer of arts not for reason that it's the aim of Sufi path but due to reason that it's in Sufism preaching to become more aware of Divine Beauty that reveals everywhere. Due to which Sufi create beautiful things in accordance of beauty of his specific nature and also according to the conventional artistic rules that replicate the Beauty of the Supreme Artisan. Sufism lays where love and facts combine, and the final and mutual object of knowledge and love is no one except the Divine Beauty. It thus can be observed that art in theocentric culture like Islam is linked with mysticism of Islam which is the inner aspect of Sufism tradition.

\section{List of Figures}
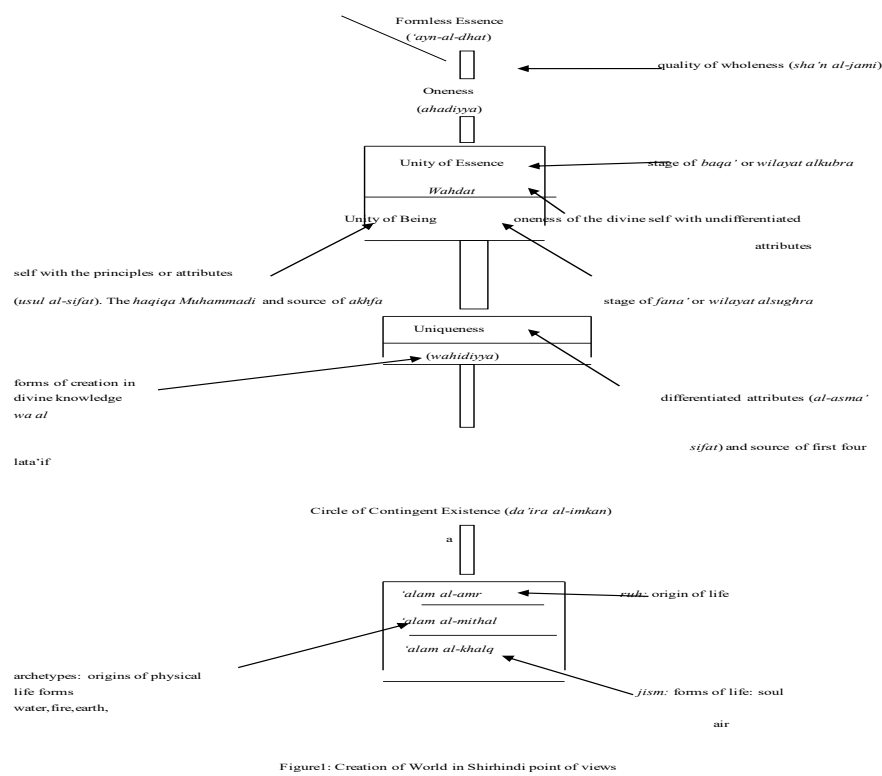

Figure. 1: Creation of World in Shirhindi point of views 


\section{Muhammad Ahsan Bilal \& Sonia Nasir Khan}

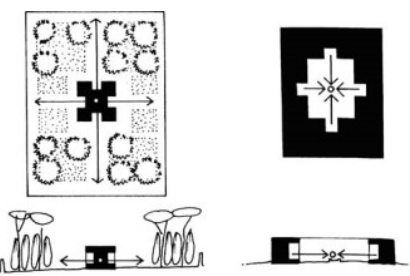

Figure 2: Reflection of cosmos in garden concept

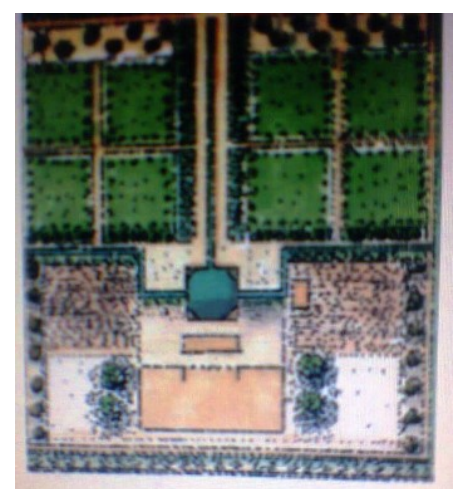

Figure 3: showing the layout of a Chahar-bagh, considered to be a \prototype of Islamic ga rdens all over the world.

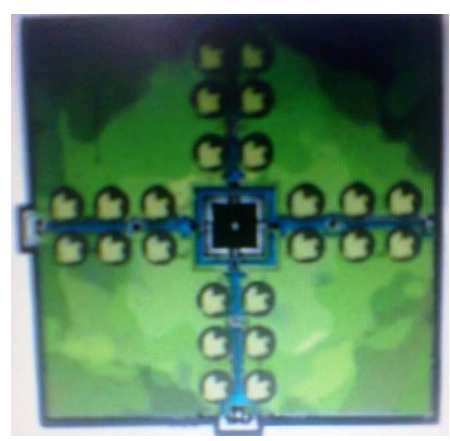

Figure 4: A garden with four rivers of the Paradise, and a mple shade from sun, fruit bearing trees and fragrant flowers is created 
Perennial Journal of History, Vol II. No. II

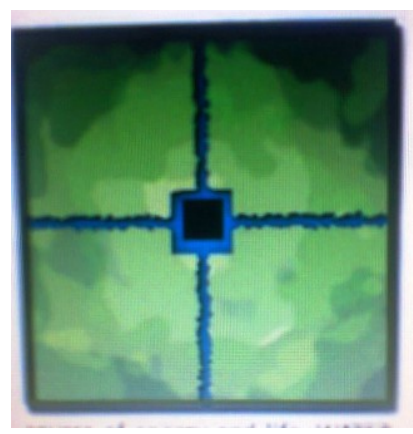

Figure 5: Four parts, four corners, creation of mandala, Source of energy and life, Water placed at the centre of the garden 


\section{Muhammad Ahsan Bilal \& Sonia Nasir Khan}

\section{References}

1. Arberry, Arthur J.,An Introduction to the History of Su fism: The Sir Abdulla h Suhrawardy lectures for 1942, Orient Longman Limited, New Delhi, 1992.P. 44

2. Baldick, Julian. Mystical Islam: An Introduction to Sufism. Washington Square, NY: New York University Press, 1989. PP. 28, $45-54,78$

3. Bakhtiar, Laleh. SUFI Expressions of Mystic Quest. Great Britian: Thames and Hudson, 1976. PP 63, 80, 112,

4. Brookes, John. Gardens ofParadise: The History and Design of the Great Islamic Gardens. New York, United States: New Amsterdam Books 1998.P 115

5. Chittick, William C. The Sufi Path of Knowledge: Ibn al-'arabi's Metaphysics of Imagination. Albany, NY: State University of New York Press, 1989. PP 18,35-44

6. Critchlow, Keith. Islamic Patterns an analytical and cosmological a pproach. Great Britain London: Thames and Hudson Ltd, 1976. P. 105

7. Sabiha Foster. Islam and Architecture. GreatBritain: Wiley-Academy, 2004.

8. SCHIMMEL, ANNEMARIE. Mystical Dimensions of Islam. New Delhi: YODA PRESS, 1975.pp 18,98, 111,120,

9. Lings, Martin. What is Sufism? London: George Allen and Unwen Ltd., 1975.P. 35

10. Lehman, Jonas Benzion; Earthly Paradise: ga rden a nd courtyard in Isla m. C a lifornia: University of California Press, 1980. P. 209.

11. Ruggles, D. Fairchild.. Islamic Gardens and Landscapes. Penn Press. 2009.P. 57

12. Papadopoulo, Alexandre. L'islam et l'art musulman. Paris: Edition d"eart Lucien Mazenod, 1976.

13. http://traditionalhikma.com/wp-content/uplo a ds/2015/07/What-isSufism.pdf

14. https://iri.aiou.edu.pk/indexing/wp-content/uploads/2016/06/24-sufimetaphysics.pdf

15. https://jespnet.com/journals/Vol_1_No_1_June_2014/9.pdf 